\title{
ISSUES IN MEDICINE Developing anatomical terms in an African language
}

\author{
Farai D Madzimbamuto
}

Clinical and technical information imparted in most African languages involves inexact terminology and code switching, so it lacks the explanatory power characterised by the English language. African languages are absent in the tertiary science education environment and forums where African scientists could present scientific material in the medium of African languages. This limits the development of African languages in the scientific domain. There has recently been a trend in several African languages to develop and intellectualise them, especially in the field of medical sciences.
The ChiShona language is used to explore the ability of an African language to develop new terminology, to name the vertebral skeleton and describe it scientifically. It uses word compounding to demonstrate terminology development. ChiShona has similarities with several hundred other Bantu languages in East, Central and Southern Africa. Advancing this language can promote similar developments in others, making them more explanatory for the lay public and health professionals.

S Afr Med J 2012;102:132-135.
From a medical perspective, patients prefer information in their own language, but in Africa the development of such technical language has been neglected. In Zimbabwe, clinical information in ChiShona involves inexact terminology, switching language during speech, i.e. code-switching, and inaccurate examples, whereas in English the information given can be as specific and detailed as the patient wants or understands. Most citizens do not speak English as their first language and may not be able to express adequately their illness experience. On the other hand, most health professionals lack the terminology in their African language for the information being delivered, mainly because technical knowledge develops through formal school education in English rather than through the home African language. ${ }^{1}$ So both communities would benefit from the development of the language.

The use of mother tongue as the medium of instruction at secondary and tertiary level is widely debated. Many students and their teachers translate between English and mother tongue, with varying degrees of success. ${ }^{2}$ Students are under pressure to learn to think and explain themselves in English, failure of which is seen as a barrier to accomplishment at the international level. However, students feel they would learn faster if some technical information was available in their mother tongue or some explanations and examples used local sources. Strong evidence supports accelerated learning when mother-tongue language is used alongside the language of learning. ${ }^{3,4}$ In addition, exclusive use of a dominant language stunts the growth and elaboration of lower level languages. Using the language in class as a dual language, through secondary and tertiary learning, has been identified as a way of bringing it into high-level contact with concepts in the dominant language, thus accelerating the development of its vocabulary. ${ }^{5,6}$

For these reasons, developing African languages to be able to function at a technical level and to disperse technical information to a lay level,

Dr Farai D Madzimbamuto is senior lecturer in the Department of Anaesthesia and Critical Care Medicine at the University of Botswana School of Medicine, Gaborone, Botswana thereby improving access to knowledge, has become an important area of language advocacy. During the human immunodeficiency virus (HIV) epidemic many language communities have found themselves struggling to communicate health information to their spokespeople and to overcome terminology considered vulgar and 'embarassing.'

This paper describes one approach of developing the language using the ChiShona language spoken in Zimbabwe and neighbouring countries.

\section{ChiShona language}

ChiShona is one of eight officially recognised languages in Zimbabwe and represents a cluster of languages spoken by about $80 \%$ of Zimbabweans. It is mutually intelligible with related languages in Mozambique. TjiKalanga in Zimbabwe and Botswana is closely related to ChiShona but is considered a separate language. There are more than 12 million first-language ChiShona speakers. It has the status of a national language, together with IsiNdebele. It is widely used in public discussion, on the radio and television, a print newspaper and has a body of literature. In the domain of education it is used as language of instruction in the lower levels of primary education, and is taught as a subject up to tertiary level in several universities in the country. Several Shona-English dictionaries have been published and the first monolingual dictionary was published in 2001. In 2004 a dictionary of ChiShona medical terms was published. ${ }^{8}$

\section{Terminology development}

Languages use a variety of methods for acquiring new terms. New words in ChiShona have been assimilated from English, Nguni, Afrikaans and Portuguese over the centuries. Word borrowing is one of the methods used in terminology development, for example use of the word ' wadhi' from 'ward'. Other methods include loan translation, semantic extension and compounding (examples in Table 1).

Loan translations and semantic extensions are used extensively as a way of using the language's own resources rather than borrowing. This also generates root words that can be used as compound units in systematic terminology development. As with English it is easier to explain and be understood when the lay terms or the analogies used mean the same as the technical terms, so that as the explanation deepens (through questioning) the message is not lost. There is always a dialogue between lay and technical terminology. Explaining what a facet joint is to a patient with back pain calling it a tsitsopfundo 
Table 1. Methods of terminology formation

\begin{tabular}{|c|c|c|}
\hline $\begin{array}{l}\text { Terminology word } \\
\text { formation method }\end{array}$ & Explanation & Example \\
\hline Borrowing & A term is borrowed with its meaning and 'Africanised' & $\begin{array}{l}\text { oparesheni: operation } \\
\text { dhokotera/dhokota: doctor }\end{array}$ \\
\hline Loan translation & $\begin{array}{l}\text { Form and meaning of the word in the source language is kept } \\
\text { but the word is translated using words from the target language }\end{array}$ & $\begin{array}{l}\text { kahuku mhezi (kahuku): chicken pox [huku - chicken, mhezi - rash] } \\
\text { ronga mhuri: family planning [ronga - plan (v), mhuri - family (n)] } \\
\text { pfundohudyu: hip joint [pfundo - joint, hudyu - hip] } \\
\text { duramazwi: dictionary [dura - store (n) or explain (v), mazwi - } \\
\text { words] }\end{array}$ \\
\hline Semantic extension & $\begin{array}{l}\text { The meaning of a word is modified or extended to } \\
\text { accommodate a new meaning or use }\end{array}$ & $\begin{array}{l}\text { kucheka: to cut [now also means to operate] } \\
\text { kuvhiya: originally just meant to cut up an animal. Now also } \\
\text { means 'to operate or to dissect'. }\end{array}$ \\
\hline Compounding & Two or more word are joined to form one & $\begin{array}{l}\text { mheta [folds] makumbo [legs], which describes } \\
\text { mhetamakumbo [polio] }\end{array}$ \\
\hline
\end{tabular}

\section{Table 2. Vertebral anatomical terms}

\begin{tabular}{|c|c|c|}
\hline Anatomical structure & Descriptors in Shona & Compounding units \\
\hline spinal column & $\begin{array}{l}\text { muzongoza }(\text { sing }) \\
\text { mizongoza }(\mathrm{pl})\end{array}$ & muzongoza \\
\hline vertebra & $\begin{array}{l}\text { zongoza }(\text { sing }) \\
\text { mazongoza }(\mathrm{pl})\end{array}$ & zongozo \\
\hline body & $\begin{array}{l}\text { tsiga - putting one object on top of another } \\
\text { mutsigozongoza (the load bearing, 'carrying' part of vertebra) } \\
\text { mutumbi - body }\end{array}$ & $\begin{array}{l}\text { tsigo - } \\
\text { mutumbi }\end{array}$ \\
\hline pedicle & $\begin{array}{l}\text { bango or mbiru are the poles that hold up an arch or roof } \\
\text { mbiru yezongoza }\end{array}$ & $\begin{array}{l}\text { bango } \\
\text { mbiru }\end{array}$ \\
\hline arch & chingo is arch & chingo \\
\hline spinous process & tsuvi is spire of building & tsuvi \\
\hline lamina & nhungo is a roof pole, when several strapped together form a lattice & nhungo \\
\hline transverse process & $\begin{array}{l}\text { chinjiko is 'transverse' or 'across' } \\
\text { nyanga is 'horn' }\end{array}$ & $\begin{array}{l}\text { chinjiko } \\
\text { nyanga }\end{array}$ \\
\hline tubercle & bundu/pundu is a swelling & $\begin{array}{l}\text { bundu } \\
\text { pundu }\end{array}$ \\
\hline foramen & $\begin{array}{l}\text { buri is an opening } \\
\text { mwena is a canal } \\
\text { guru is a cavern }\end{array}$ & $\begin{array}{l}\text { buri } \\
\text { mwena } \\
\text { guru }\end{array}$ \\
\hline sacrum & hungunyo (or gungunyo) is sacral bone & hungunyo \\
\hline articular facets & tsitso is a footing or where one thing steps on another, and tsitsa is to step on another & tsitso \\
\hline intervertebral discs & hata is a pad or cushion such as is interposed between loads & hata \\
\hline $\begin{array}{l}\text { notches [vertebral } \\
\text { notches] }\end{array}$ & nazho is a notch & n'azho \\
\hline (anatomical) planes & $\begin{array}{l}\text { usandara (husandara) means flatness and uchechetere (huchechetere) means 'same level' and } \\
\text { are used to refer to planes or flatness. These are key terms in anatomical descriptions. }\end{array}$ & $\begin{array}{l}\text { usandara } \\
\text { uchechetere }\end{array}$ \\
\hline anterior & mberi means 'forward', kumberi 'towards the front' & mberi \\
\hline ventral & muhamba means 'the underside of an animal' & hamba \\
\hline posterior & seri means 'behind', kuseri 'towards the back' & seri \\
\hline superior & soro means 'headward', kusoro 'towards the head' & soro \\
\hline inferior & $z a s i$ 'downward' or uswe 'tailwards' & zasi or uswe \\
\hline lateral & divi or rutivi means 'sidewards', kudivi 'towards the side & divi \\
\hline medial & pakati 'middle', neche mukati towards midline & mukati \\
\hline
\end{tabular}


Table 3. Derived compound terms

\begin{tabular}{|c|c|c|c|c|}
\hline $\begin{array}{l}\text { Structure in anatomical } \\
\text { english }\end{array}$ & & und units & Shona compound term & Shona 'back translation' \\
\hline vertebral foramen & $\begin{array}{l}\text { buri } \\
\text { zongoza }\end{array}$ & foramen vertebra & burizongoza & 'opening' in the vertebra \\
\hline transverse foramen & $\begin{array}{l}\text { buri } \\
\text { chinjiko }\end{array}$ & foramen transverse & $\begin{array}{l}\text { burichinjiko or } \\
\text { burijinjiko }\end{array}$ & 'opening' in the 'cross' bone \\
\hline vertebral canal & $\begin{array}{l}\text { mwena } \\
\text { zongoza }\end{array}$ & $\begin{array}{l}\text { canal } \\
\text { vertebra }\end{array}$ & mwenamuzongoza & 'canal' in the vertebral column \\
\hline sacral canal & $\begin{array}{l}\text { mwena } \\
\text { guru } \\
\text { hungunyo }\end{array}$ & $\begin{array}{l}\text { canal } \\
\text { cavern } \\
\text { sacral }\end{array}$ & $\begin{array}{l}\text { mwenahungunyo or } \\
\text { guruhungunyo }\end{array}$ & $\begin{array}{l}\text { 'canal' in sacrum or } \\
\text { 'cavern' in sacrum }\end{array}$ \\
\hline intervertebral canal & $\begin{array}{l}\text { buri } \\
\text { nazho }\end{array}$ & $\begin{array}{l}\text { foramen } \\
\text { notch }\end{array}$ & burirenazho & 'opening' of notches \\
\hline superior articular process & $\begin{array}{l}\text { tsitso } \\
\text { soro }\end{array}$ & $\begin{array}{l}\text { articular } \\
\text { superior }\end{array}$ & tsitsosoro & $\begin{array}{l}\text { footing, } \\
\text { upper (superior) }\end{array}$ \\
\hline inferior articular process & $\begin{array}{l}\text { tsitso } \\
\text { zasi }\end{array}$ & $\begin{array}{l}\text { articular } \\
\text { inferior }\end{array}$ & tsitsozasi & $\begin{array}{l}\text { footing, } \\
\text { lower (inferior) }\end{array}$ \\
\hline transverse articular process & $\begin{array}{l}\text { tsitso } \\
\text { chinjiko }\end{array}$ & $\begin{array}{l}\text { articular } \\
\text { transverse }\end{array}$ & tsitsochinjiko & $\begin{array}{l}\text { footing, } \\
\text { transverse (cross) bone }\end{array}$ \\
\hline transverse process & $\begin{array}{l}\text { nyanga } \\
\text { chinjiko }\end{array}$ & process transverse & $\begin{array}{l}\text { chinjiko, jinjiko } \\
\text { nyangachinjiko }\end{array}$ & $\begin{array}{l}\text { cross bone } \\
\text { cross bone projection }\end{array}$ \\
\hline transverse tubercle & $\begin{array}{l}\text { pundu } \\
\text { chinjika }\end{array}$ & $\begin{array}{l}\text { tubercle } \\
\text { transverse }\end{array}$ & punduchinjiko & swelling on cross bone \\
\hline $\begin{array}{l}\text { posterior tubercle } \\
\text { anterior tubercle }\end{array}$ & $\begin{array}{l}\text { pundu } \\
\text { posterior } \\
\text { anterior }\end{array}$ & $\begin{array}{l}\text { tubercle } \\
\text { seri } \\
\text { mberi }\end{array}$ & $\begin{array}{l}\text { punduseri } \\
\text { pundumberi }\end{array}$ & $\begin{array}{l}\text { back swelling } \\
\text { front swelling }\end{array}$ \\
\hline spinous process (of vertebra) & $\begin{array}{l}\text { tsuvi } \\
\text { (zongoza) }\end{array}$ & $\begin{array}{l}\text { spire } \\
\text { (vertebrae) }\end{array}$ & tsuvizongoza & spire on vertebra \\
\hline spinous tubercle & $\begin{array}{l}\text { pundu } \\
\text { tsuvi }\end{array}$ & $\begin{array}{l}\text { tubercle } \\
\text { spire }\end{array}$ & pundutsuvi & swelling on spire \\
\hline
\end{tabular}

(tsitso - facet and pfundo - joint) is much simpler than attempting to use the borrowed term faseti jointi. As more African terminology is used it will become familiar to the public who have become familiar with English terminology. The English-speaking public has begun to use technical terms as the educational level has increased and more technical information is available in the public domain. An additional benefit when using the language's own resources is that knowledge already embedded in the language is not lost, but becomes available and used in a new way. ${ }^{9}$

This paper focuses on word compounding as a way to demonstrate the language's ability to form new technical terms, using anatomical terms as a model. Table 2 shows how the compound units are derived for use in the terms shown in Table 3, as developed by the author.

\section{Medical dictionaries}

Medical dictionaries record the words in current use. Necessarily the lists consist of words that enter the language through all available methods including borrowing, translating, semantic extension, etc. The KiSwahili dictionary, Kamusi ya Tiba, aimed primarily at health professionals, uses English headwords with KiSwahili definitions and explanations. ${ }^{10}$ The English-Xhosa Companion is for communication between health professionals and the lay public. Most of the vocabulary is original Xhosa terms, loan translations and semantic extensions with few borrowed words. ${ }^{11}$ The ChiShona Duramazwi reUrapi neUtano (Dictionary of Medical and Health
Terms) is aimed at Shona-speaking health professionals. It contains headwords in ChiShona with definitions in ChiShona. It is not the function of dictionaries to determine how new words are to be coined or used, although they may legitimise a new word for some time. In the final analysis it is the users or language speakers who determine whether a word will be used and remain in the lexicon.

\section{Discussion}

Many terms can be generated in ways which carry with them some of the meaning of their original source words, similar to the method used with Latin and Greek terms in medical terminology to generate new words, e.g. cardiology $=$ cardi + ology (heart + study of $)$. Compound noun formation is one of several different methods of developing new terminology for language.

Linguists who have led dictionary development in ChiShona and other African languages have emphasised the importance of developing terminology in African languages. Terminology development in science and technology is more difficult because many African scientists may have no formal training in their mother tongue or another African language and language specialists usually have little background in sciences. Thus collaboration between scientists and linguists is essential. Language teaching needs to come back into medical schools, as Latin and Greek were taught in the past in Europe, to raise the level at which African languages are used by first-language speakers so that 
terminology development in these domains can fully engage with subject expertise. Currently it is used to improve language skills for communication between health professionals from different language groups and patients. 'Dual' language use at tertiary level has been used and explored as a way of ensuring that African languages have a presence at tertiary level in non-language subjects and this has contributed to language development. ${ }^{12-14}$ Language develops through being used. African languages development can be promoted further by:

- using them in the tertiary environment as 'dual' language teaching, as with other languages such as Afrikaans in South Africa

- developing space where African language use is promoted in publications and scientific meetings

- increasing the use of African languages in medical education so that African culture may be less 'other' or marginalised.

\section{Conclusion}

Developing African languages so that they can be used in all the domains of language use is increasingly seen as urgent. The experience of few languages, such as Swahili and Afrikaans, that have had the political and organisational support to make significant progress, must be extended to others. There are many approaches to terminology development, such as word compounding, that mine the rich source of knowledge already embedded in the African languages. With Bantu languages, compounding can generate an endless vocabulary with similar systematic potential to the use of Latin and Greek in other European languages. Science and technology, including medicine, have tended to lag behind, but if scientists and linguists collaborate in this task, our languages in Africa have great possibilities.

1. Mbananga $\mathrm{N}$, Mniki S, Oelefse A, et al. A model for developing medical terms in indigenous languages: a step towards consumer informatics in South Africa. In: Fieschi M, Coiera E, Yu-Chan JL, eds. Proceedings of the $11^{\text {th }}$ World Congress on Medical Informatics. Pt 2. Washington: IOS Press: 2004: 1216-1218

2. Brock-Utne B, Hollmarsdottir H. Language policies and practices in Tanzania and South Africa: problems and challenges. Int J Educ Dev 2004;24:67-83.

3. Van Rooyen D, Jordaan H. An aspect of language for academic purposes in secondary education complex sentence comprehension by learners in an integrated Gauteng school. South African Journal of Education 2009;29:271-287.

4. Pluddemann P, Braam D, October M, Wababa Z. Dual-medium and parallel-medium schooling in the Western Cape: from default to design. PRAESA Occasional Paper No17. Cape Town, UCT: 2004.

5. Ramani E, Kekana T, Modiba M, Joseph M. Terminology development versus concept development through discourse: insights from a dual-medium BA degree. Southern African Linguistics and Applied Language Studies 2007;25:207-223.

6. Obanya P. Learning in, with and from first language. PRAESA Occasional Paper No 19. Cape Town, UCT: 2004.

7. Kruger A. Translating public information texts on health issues into languages of limited diffusion Kruger A. Translating public information texts on health issues into languages of limited diffusion
in South Africa. In: Valdeón RA, ed. Translating Information. Oviedo: University of Oviedo Press, in South Afric

8. Mpofu N, Chimhundu H, Mangoya E, Chabata E. Duramazwi reUrapi neUtano ALLEX Projec University of Zimbabwe and Mambo Press. 2004.

9. Dlodlo TS. Science nomenclature in Africa: Physics in Nguni. Journal of Research in Science Teaching 1999;36:321-331.

10. Mwita AMA, Mwansoko HJM. Kamusi ya Tiba . Dar es Salaam: Chuo Kikuu cha Dar es Salaam, 2003. 1. Kirsch B, Skorge S, Matsikiza N. An English-Xhosa Companion for Health Care Professionals. Cape Town: Juta, 1996.

2. Musau PM. Adapting an African language as a medium of instruction at the university: the case of Kiswahili in Kenya. Poznan Studies in Contemporary Linguistics 2001;37:127-137.

13. Du Plessis T. Perspectives on managing Afrikaans and English as 'equal' languages of learning and teaching at the University of the Free State. Southern African Linguistics and Applied Language Studies 2007:26:315-332.

14. Blaauw J. Sourcing and maintaining a pool of suitably skilled interpreters for educational interpreting at a tertiary institution. Southern African Linguistics and Applied Language Studies 2008;26:301-303. 